NBER WORKING PAPER SERIES

ARE COUNTERCYCLICAL FISCAL POLICIES COUNTERPRODUCTIVE?

David B. Gordon

Eric M. Leeper

Working Paper 11869

http://www.nber.org/papers/w11869

NATIONAL BUREAU OF ECONOMIC RESEARCH

1050 Massachusetts Avenue

Cambridge, MA 02138

December 2005

The views expressed herein are those of the author(s) and do not necessarily reflect the views of the National Bureau of Economic Research.

(C2005 by David B. Gordon and Eric M. Leeper. All rights reserved. Short sections of text, not to exceed two paragraphs, may be quoted without explicit permission provided that full credit, including $@$ notice, is given to the source. 
Are Countercyclical Fiscal Policies Counterproductive?

David B. Gordon and Eric M. Leeper

NBER Working Paper No. 11869

December 2005

JEL No. E32, E62, E63

\begin{abstract}
$\underline{\text { ABSTRACT }}$
Economists generally believe that countercyclical fiscal policies have stabilizing effects that work through automatic stabilizers and discretionary actions. Analyses underlying this conventional wisdom focus on intratemporal margins: how employment and personal income respond in the short run to changes in government expenditures and taxes. But in economic downturns, countercyclical policies increase government indebtedness, raising future debt service obligations. These new expenditure commitments must be financed by some mix of higher taxes, lower spending, or higher money growth in the future. Expectations of how future policies will adjust change current savings rates and the efficacy of countercyclical policies. It is thus possible for responses to expected future policies to exacerbate and prolong recessions. This paper highlights these expectations effects. Connecting the theory to U.S. data we find: (1) through this expectations channel, countercyclical policies may create a business cycle when there would be no cycle in the absence of countercyclical policies; (2) nontrivial fractions of variation in investment and velocity can be explained by variation in macro policies alone---without any nonpolicy sources of fluctuation; and (3) persistence in key macro variables can arise solely from expectations of policy.

David B. Gordon

gd@clemson.edu

Eric M. Leeper

Department of Economics

304 Wylie Hall

Indiana University

Bloomington, IN 47405

and NBER

eleeper@indiana.edu
\end{abstract}




\title{
ARE COUNTERCYCLICAL FISCAL POLICIES COUNTERPRODUCTIVE?
}

\author{
DAVID B. GORDON AND ERIC M. LEEPER
}

\section{INTRODUCTION}

Economists generally believe that countercyclical fiscal policies have stabilizing effects that work through both automatic stabilizers and occasional discretionary actions. ${ }^{1}$ Analyses underlying this conventional wisdom focus on intratemporal margins: how employment and personal income respond in the short run to changes in government expenditures and taxes.

But in economic downturns, countercyclical policies increase government indebtedness, raising future debt service obligations. And these new expenditure commitments must be financed by some mix of higher taxes, lower spending, and higher money growth in the future. Expectations of how future policies will adjust change current savings rates and can matter for the efficacy of countercyclical policies. ${ }^{2}$ Indeed, it is possible for responses to expected future policies to exacerbate and prolong recessions.

Countercyclical fiscal policies necessarily create dynamic links between current and future policies. Although the ultimate response of the aggregate economy to countercyclical policies must include an intertemporal dimension, many analyses break this intertemporal link and place the implications of expectations of future policies in the background.

We employ a general framework in which macro policies affect both intratemporal and intertemporal margins. This paper specializes the general framework to present results that highlight the role of expectations effects. Three findings emerge:

Date: December 6, 2005. Department of Economics, Clemson University, gd@clemson.edu; Department of Economics, Indiana University and NBER, eleeper@indiana.edu.

${ }^{1}$ See, for example, Duesenberry, Eckstein, and Fromm (1960), Hansen (1969), Blinder and Solow (1973), Baily (1978), Tobin (1980), Christiano (1984), Romer and Romer (1994), Chatterjee (1999), Romer (1999), Auerbach and Feenberg (2000), Cohen and Follette (2000), and Taylor (2000).

${ }^{2}$ Baxter and King (1993) emphasize that the impacts of government spending changes depend on how the spending is financed. 
- Through the expectations channel, countercyclical policies may be counterproductive by creating a business cycle when there would be no cycle in the absence of countercyclical policies.

- Nontrivial fractions of variation in investment and velocity can be explained by variation in macro policies alone - without any nonpolicy sources of fluctuation.

- Persistence in key macro variables can arise solely from expectations of policy.

These findings are provocative. They do not necessarily contradict the view that on net countercyclical policies have been effective. But given the counterproductive effects stemming from expectations effects, if conventional wisdom is correct that countercyclical policies dampen the cycle, the intratemporal effects must be substantially more powerful than earlier studies have claimed.

We derive these findings from simple dynamic reasoning that leads to the counterproductivity of countercyclical fiscal policies and then tie that logic to U.S. data to find empirical support for the reasoning. The economic logic is straightforward: during an economic downturn countercyclical policies create a debt-financed budget deficit; if agents expect that taxes will rise in the future, then the expected return on investment declines, exacerbating any reduction in investment associated with the downturn. With the capital stock lower than it would otherwise be, output remains low for a longer period: the downturn is deeper and more prolonged than it would be in the absence of countercyclical policies.

We connect this reasoning to U.S. data on policy variables. Equating expectations to realizations of policies - imposing perfect foresight — we simulate a dynamic general equilibrium monetary model, calibrated to U.S. data. We find that realizations of current and expected policy variables alone generate a cycle in investment and money demand that coincides with the NBER business cycle dates. In the absence of any change in current or expected policies, portfolio choices would be constant in the model, so any cycle obtained from the simulation is generated solely by policy.

Auerbach (2003) discusses a number of reasons why it is difficult to find persuasive evidence of the impacts of fiscal policy on the economy. He singles out expectations as the most difficult problem. Although perfect foresight is an extreme assumption about how agents form expectations of policy, it is nonetheless striking that we find compelling evidence that expected fiscal policies matter. Our emphasis on expectations contrasts with the often complete absence of a role for expectations in work underlying the conventional wisdom that countercyclical policies effectively stabilize the economy (Romer and Romer 1994). ${ }^{3}$

\footnotetext{
${ }^{3}$ See also Sargent's (2002) comments on Romer and Romer (2002).
} 
Although they may contradict conventional wisdom, our findings are in line with recent results from dynamic stochastic general equilibrium models. Chari, Christiano, and Kehoe (1994) find that optimal fiscal policy improves on observed U.S. policies both by reducing the variability of key macro variables and by raising welfare. Jones (2002) fits a model to U.S. data and finds that fiscal policy provided little stabilization and in some cases may be destabilizing. Our findings certainly confirm that actual policy behavior has increased the variance of investment and velocity and prolonged, rather than shortened, economic downturns.

Bohn's (1991) work can be viewed as providing empirical support for the existence of the expectations channel. He finds that historically U.S. government debt expansions have been followed by subsequent spending cuts and tax increases. Our results may be interpreted as reporting the business cycle consequences of Bohn's findings.

The paper begins by laying out a general theoretical structure in which expectations of policy play a key role in determining the current equilibrium. To obtain the analytical solutions required to completely specify the dependence of the equilibrium on current and expected policies, we restrict the model by assuming specific functional forms. In the following sections we calibrate the model to U.S. data and simulate perfect foresight paths using U.S. policy variables. The resulting simulated time series are solely a product of realizations of current and expected policy variables, with no nonpolicy exogenous shocks.

\section{A General Framework}

This section describes a general equilibrium model of fiscal finance in the spirit of Chari, Jones, and Manuelli (1995). Like Sargent and Wallace (1981), we model only the fiscal financing role of monetary policy.

As in Heckman (1976) and Lucas (1988), the household supplies effective labor given by $h n$, where $h$ is human capital and $n$ is hours worked. Gross output is produced with the constant returns to scale technology $f(k, h n)$, where $k$ is physical capital. We denote gross output at $t, f\left(k_{t-1}, h_{t-1} n_{t}\right)$, by $f(t)$. Output net of undepreciated capital, $y_{t}$, satisfies the accounting identity:

$$
c_{t}+x_{k t}+x_{h t}+g_{t}=y_{t}
$$

where $x_{k}$ and $x_{h}$ are investment in physical and human capital, and $g$ is government purchases. The two capital stocks evolve according to

$$
k_{t}=x_{k t}+d^{k}\left(k_{t-1}, h_{t-1} n_{t}\right)
$$




$$
h_{t}=x_{h t}+d^{h}\left(k_{t-1}, h_{t-1} n_{t}\right),
$$

where $d(\cdot, \cdot)$ represents undepreciated capital, which we denote by $d(t)$.

2.1. Firms. There are two representative firms that rent factors of production from households and sell their outputs back to households. The goods producing firm rents $k$ at rental rate $r$ and hires effective labor $h n$ at wage rate $w$ to solve

$$
\max _{k_{t-1}, h_{t-1}, n_{t}} D_{G t}=f\left(k_{t-1}, h_{t-1} n_{t}\right)-r_{t} k_{t-1}-w_{t} h_{t-1} n_{t} .
$$

The transactions services producing firm hires labor $l$ at wage rate $w_{T}$ to solve

$$
\max _{l_{t}} D_{T t}=P_{T t} T\left(l_{t}\right)-w_{T t} l_{t}
$$

with $P_{T}$ the price of transactions services relative to consumption goods. Production functions are strictly concave and differentiable. Both firms behave competitively, taking all prices as given.

2.2. Households. The representative household owns the firms and pays taxes on capital and labor income. It has disposable income

$$
I_{t}=\left(1-\tau_{t}^{k}\right) r_{t} k_{t-1}+\left(1-\tau_{t}^{n}\right) w_{t} h_{t-1} n_{t}+\tau_{t}^{k} d^{k}(t)+\tau_{t}^{n} d^{h}(t)+D_{G t}+w_{T t} l_{t}+D_{T t}+z_{t},
$$

where $z$ is transfer payments from the government. Because $r$ and $w n$ are the returns on gross capital assets, we add back the tax levied against income derived from undepreciated capital stocks.

The household's expenditures on consumption and new capital goods at date $t$ must be financed with real money balances carried over from the previous period, $M_{t-1} / P_{t}$, or with transactions services, $T_{t}$, to satisfy the constraint

$$
\frac{M_{t-1}}{P_{t}}+T_{t}\left(c_{t}+x_{t}\right) \geq c_{t}+x_{t}
$$

where $x_{t}=x_{k t}+x_{h t}$ is total investment in capital. Transactions services can be thought of as a clearinghouse, money market mutual funds, or credit cards and the labor supplied to that sector reflects resources used in producing the services. Those resources should not be construed as "labor supply" in the same sense that $n_{t}$ is.

The household consists of a worker-shopper pair. Each member of the household is endowed with a unit of time. The worker supplies $n_{t}$ units of time to the goods producing firm and the shopper supplies $l_{t}$ units of time to the transactions services producing firm; the two kinds of labor are not substitutable. The household solves 


$$
\max _{\left\{c_{t}, l_{t}, n_{t}, T_{t}, M_{t}, B_{t}, k_{t}, h_{t}\right\}} E_{0} \sum_{t=0}^{\infty} \beta^{t} U\left(c_{t}, l_{t}, n_{t}\right), \quad 0<\beta<1,
$$

where $1-n_{t}$ is leisure for the worker and $1-l_{t}$ is leisure for the shopper, subject to (7), the budget constraint

$$
c_{t}+k_{t}+h_{t}+\frac{M_{t}+B_{t}}{P_{t}}+P_{T t} T_{t} \leq I_{t}+\frac{M_{t-1}+\left(1+i_{t-1}\right) B_{t-1}}{P_{t}},
$$

the evolution of the capital stocks, (2) and (3), and $0 \leq n_{t}, l_{t} \leq 1$. Future government policy is the sole source of uncertainty; the operator $E$ in (8) denotes equilibrium expectations of private agents over future policy. $B_{t}$ is purchases of nominal oneperiod government debt issued at $t$ and $i_{t}$ is the net nominal interest rate on debt issued at $t$ and due at $t+1$. The household starts with initial assets $k_{-1}>0, h_{-1}>0$, and $M_{-1}+\left(1+i_{-1}\right) B_{-1}>0$.

The government finances expenditures on goods, $g_{t}$, and transfer payments, $z_{t}$, by levying taxes, issuing new debt, and creating new money to satisfy the restraint:

$\tau_{t}^{k}\left[r_{t} k_{t-1}-d^{k}(t)\right]+\tau_{t}^{n}\left[w_{t} h_{t-1} n_{t}-d^{h}(t)\right]+\frac{M_{t}-M_{t-1}}{P_{t}}+\frac{B_{t}-\left(1+i_{t-1}\right) B_{t-1}}{P_{t}}=g_{t}+z_{t}$.

\section{An Intertemporal Example}

To analyze the potential for countercyclical policies to be counterproductive, we specialize the model to obtain the analytical solutions required to completely specify how the current equilibrium depends on current and expected policies. The specialization highlights the expectations channel through which countercyclical policies affect the economy. It is also convenient to consider future policies that are constant but may differ from current policies. This allows us to derive analytically the dynamic linkages between current and future policies in equilibrium.

3.1. Assumptions. Assume labor is supplied inelastically to goods production (as in Jones, Manuelli, and Rossi 1993) and set $\tau_{t}^{k}=\tau_{t}^{n}=\tau_{t}$. Further assume the following functional forms:

$$
\begin{gathered}
f\left(k_{t-1}, h_{t-1}\right)=k_{t-1}^{\sigma} h_{t-1}^{1-\sigma}, \quad 0<\sigma<1, \\
T\left(l_{t}\right)=1-\left(1-l_{t}\right)^{\alpha}, \quad \alpha>1,
\end{gathered}
$$




$$
U\left(c_{t}, l_{t}, 1\right)=\log \left(c_{t}\right)+\gamma \log \left(1-l_{t}\right), \quad \gamma>0,
$$

with $\gamma / \alpha<1$,

$$
\begin{gathered}
d^{k}\left(k_{t-1}, h_{t-1}\right)=\sigma\left(1-\delta_{k}\right) f\left(k_{t-1}, h_{t-1}\right), \\
d^{h}\left(k_{t-1}, h_{t-1}\right)=(1-\sigma)\left(1-\delta_{h}\right) f\left(k_{t-1}, h_{t-1}\right),
\end{gathered}
$$

with $0 \leq \delta_{k}, \delta_{h} \leq 1$. $^{4}$

There are no exogenous "shocks" to technology, preferences, or endowments. Realizations of current and expected policy variables are the sole source of variation.

3.2. Solution ${ }^{5}$. With these restrictions the equilibrium can be defined in terms of policy expectations, initial assets, and current government policy.

Our results focus on two aspects of portfolio choice: investment and money demand. We express the choices in terms of their stationary counterparts - investment as a share of expenditures and velocity.

Combining the Euler equations for physical and human capital yields a solution for the total capital stock:

$$
k_{t}+h_{t}=\left(1-\frac{1}{\eta_{t}}\right)\left(1-\delta_{\sigma} s_{t}^{g}\right) f\left(k_{t-1}, h_{t-1}\right),
$$

where $s_{t}^{g} \equiv g_{t} / y_{t}, \delta_{\sigma}=1-\sigma\left(1-\delta_{k}\right)-(1-\sigma)\left(1-\delta_{h}\right)$, and

$$
\eta_{t} \equiv E_{t} \sum_{i=0}^{\infty} \beta^{i} d_{i}^{\eta}\left[1-\beta \frac{\gamma}{\alpha}\left(\frac{1-\tau_{t+i+1}}{1-s_{t+i+1}^{g}}\right)\right], \quad d_{i}^{\eta} \equiv \prod_{j=0}^{i-1} \frac{1-\delta_{\sigma} \tau_{t+j+1}}{1-\delta_{\sigma} s_{t+j+1}^{g}}, \quad d_{0}^{\eta} \equiv 1
$$

Symmetry between the two capital stocks implies that in equilibrium $h_{t} / k_{t}=(1-$ $\sigma) / \sigma$. Using this proportionality together with the solution (16) and the laws of motion for capital, we derive the investment ratio:

$$
\frac{x_{k t}}{c_{t}+x_{k t}}=\frac{\sigma\left[\left(1-\frac{1}{\eta_{t}}\right)\left(1-\delta_{\sigma} s_{t}^{g}\right)-\left(1-\delta_{k}\right)\right]}{(1-\sigma) \frac{1}{\eta_{t}}\left(1-\delta_{\sigma} s_{t}^{g}\right)+\sigma\left[\left(1-\delta_{\sigma} s_{t}^{g}\right)-\left(1-\delta_{k}\right)\right]} .
$$

Solving the Euler equation for money yields

\footnotetext{
${ }^{4}$ This specification of depreciation is non-standard. We employ it to obtain an analytical solution, which allows clearer interpretation. In future work it will be important to check the robustness of results to the standard treatment of depreciation as proportional to the level of the capital stock.

${ }^{5}$ Appendix A derives the model solution.
} 


$$
\left(1-T_{t}\right)\left[\frac{c_{t}+x_{t}}{c_{t}}-\frac{\gamma}{\alpha}\right]=\frac{\mu_{t}}{\rho_{t}}
$$

where $\rho_{t} \equiv M_{t} / M_{t-1}$ and

$$
\mu_{t} \equiv \beta \frac{\gamma}{\alpha} E_{t} \sum_{i=0}^{\infty} \beta^{i} d_{i}^{\mu}, \quad d_{i}^{\mu} \equiv \prod_{j=0}^{i-1} \frac{1}{\rho_{t+j+1}}, \quad d_{0}^{\mu} \equiv 1 .
$$

An expression for velocity comes from using the solution (19) together with (7) and other expressions:

$$
v_{k t} \equiv \frac{c_{t}+x_{k t}}{M_{t} / P_{t}}=\frac{(1-\sigma) \frac{1}{\eta_{t}}\left(1-\delta_{\sigma} s_{t}^{g}\right)+\sigma\left[\left(1-\delta_{\sigma} s_{t}^{g}\right)-\left(1-\delta_{k}\right)\right]}{\Delta_{t} \delta_{\sigma}\left(1-s_{t}^{g}\right)}
$$

where

$$
\Delta_{t} \equiv \frac{\mu_{t}}{\left(\frac{\delta_{\sigma}\left(1-s_{t}^{g}\right)}{1-\delta_{\sigma} s_{t}^{g}}\right) \eta_{t}-\frac{\gamma}{\alpha}}
$$

3.3. Interpretation. We characterize the equilibrium at date $t$ in terms of policy expectations functions $\left(\mu_{t}, \eta_{t}\right)$, current government claims, $s_{t}^{g}$, and initial assets, $\left(k_{t-1}, h_{t-1}, M_{t-1},\left(1+i_{t-1}\right) B_{t-1}\right)$. $\left(\mu_{t}, \eta_{t}\right)$, which summarize the information agents need to form rational expectations about the equilibrium of the economy, capture the portfolio balance effects of expected policies.

$\mu$ is the marginal value of real money balances and is ubiquitous in dynamic monetary models. All else equal, changes in $\mu$ imply changes in expected inflation and the rate of return on money holdings. Expectation of a higher rate of money growthand therefore of seigniorage revenues - depreciates the value of money, lowers, $\mu$, and induces substitution away from money.

$\eta$ captures two interdependent impacts of expected policies. One impact is a direct tax distortion, which alters the private return on real assets. To isolate this effect, consider the impact of higher expected future taxes, holding future money growth and government spending shares fixed. Further suppose that debt is identically zero and, in order to focus on substitution effects, that the revenues collected through higher distorting taxes are rebated lump sum to households. Higher future taxes reduce the expected return on investment and induce agents to substitute from capital to consumption. A lower expected return on capital also induces substitutions into nominal assets, including money.

A second impact comes from $\eta$ 's summary of the composition of expected fiscal financing in terms of the relative sizes of the real and inflation tax bases. This 
trade-off can be seen heuristically from an alternative expression for the terms in $(1-\tau) /\left(1-s^{g}\right)$ that appear in the definition of $\eta$ in (62). A transformation of the government budget constraint yields: ${ }^{6}$

$$
\frac{1-\tau_{t}}{1-s_{t}^{g}}=1+\frac{\left(M_{t}-M_{t-1}+B_{t}-\left(1+i_{t-1}\right) B_{t-1}\right) / P_{t}}{\left(1-s_{t}^{g}\right) f(t)}, \quad t \geq 0 .
$$

Terms in $(1-\tau) /\left(1-s^{g}\right)$ reflect the fraction of private resources absorbed by the acquisition of new nominal liabilities issued by the government. Higher $\eta$ indicates an expected shift in future financing that expands the inflation tax base and contracts the real tax base. By reflecting the relative sizes of the two tax bases, changes in $\eta$ generate an expected inflation effect that is not embedded in the nominal interest rate.

Expression (18) shows that the total impact of countercyclical fiscal policies consists of a direct effect, associated with fixed $\eta$, and an amplification effect, due to induced changes in $\eta$. Countercyclical policy raises $s_{t}^{g}$ when the economy contracts. Hold expected policies fixed initially. Expansionary fiscal policy has a direct (negative) effect on investment, and the elasticity of that direct effect depends on $\eta_{t}$, the index of expected policies being held fixed. Direct effects arise because an increase in $s_{t}^{g}$ reduces current disposable income; how that reduction gets apportioned between consumption and investment depends on $\eta_{t}$. A lower value of $\eta$ reflects an expectation of either higher taxes or lower government spending. Lower $\eta$ raises the elasticity of equilibrium investment with respect to current government spending.

A second effect of countercyclical fiscal policies may arise. If higher $s_{t}^{g}$ induces agents to change their expectations of future tax rates or government spending shares, then the direct effects may get amplified. Suppose that debt-financed cyclical increases in spending create a recognition that future taxes must rise. This reduces $\eta_{t}$, amplifying the reduction in investment that higher $s_{t}^{g}$ entails.

Expected policies may increase velocity in two ways. First, higher expected money growth reduces the return on real balances (lower $\mu$ ) and induces substitution out of money into transactions services. Second, lower expected taxes or higher expected government spending (higher $\eta$ ) induces substitution out of nominal assets into real assets.

3.4. Equilibrium Expectations. Equilibrium requires that current and future policies satisfy the government's budget constraint and that agents' expectations of policy

\footnotetext{
${ }^{6}$ For simplicity we show this for the case of complete depreciation of capital and no government transfers.
} 
are consistent with equilibrium. This creates interactions among current and future policies, whose characterization is a novel feature of this paper.

We focus on circumstances in which the economy is in a stationary equilibrium in the future (dates $s>t$ ), but starts from some other position at date $t$. Assume future policies are constant:

$$
\rho_{t+j}=\rho_{F}, \quad \tau_{t+j}=\tau_{F}, \quad s_{t+j}^{g}=s^{g}, \quad s_{t+j}^{z}=s^{z}, \quad j>0,
$$

where $s_{t}^{z}=z_{t} / y_{t}$.

The government budget constraint can be expressed entirely in terms of current and expected policies. In period $t$ the constraint is

$$
\left[\frac{\rho_{t}-1}{\rho_{t}}+\frac{B_{t}}{M_{t}}-\frac{\left(1+i_{t-1}\right)}{\rho_{t}} \cdot \frac{B_{t-1}}{M_{t-1}}\right] \Delta_{t}=\frac{s_{t}^{g}+s_{t}^{z}-\tau_{t}}{1-s_{t}^{g}} .
$$

Given expectations of policy embedded in $\Delta_{t}$ and initial government indebtedness as summarized by $\left(1+i_{t-1}\right) B_{t-1} / M_{t-1},(25)$ reports equilibrium trade-offs among current policies.

We now derive equilibrium trade-offs among future policies given the state of government indebtedness. Shift the timing of (25) forward one period and assume future interest liabilities are correctly anticipated at $t$ by substituting the expression for equilibrium $i_{t}$. For simplicity, assume the bond-money ratio is constant at $(B / M)_{F}$ in the stationary equilibrium. Re-labeling variables dated $t+1$ with an " $F$ " subscript and imposing equilibrium yields

$$
\Delta_{t}=\left[\frac{s_{F}^{g}+s_{F}^{z}-\tau_{F}}{1-s_{F}^{g}}\right] \cdot \frac{1}{\left[\left(\frac{B}{M}\right)_{F}-\frac{1}{\beta}\left(\frac{B}{M}\right)_{t}+\left(\frac{\rho_{F}-1}{\rho_{F}}\right)\right]} .
$$

Given government indebtedness carried into the future, as summarized by $(B / M)_{t}$, (26) describes the trade-offs among future policies that are consistent with fixed $\Delta_{t}$ being an equilibrium.

Trade-offs between (25) and (26) determine the interactions between current policies and expectations of future policies. Any change in policy at $t$ that requires a change in $\Delta_{t}$ must be accompanied by a change in policy at date $F$ that is consistent with the new values of $\Delta_{t}$ and the new level of government liabilities, $(B / M)_{t}$.

\section{Data Considerations}

As a first step to link the theory with data, we use U.S. data on the policy variables, $\left\{\tau_{t}, s_{t}^{g}, s_{t}^{z}, \rho_{t}\right\}$, together with a calibration of the model to compute time series 
for $\left\{\mu_{t}, \eta_{t}\right\}$. Countercyclical fiscal policies contain two components - automatic stabilizers and "discretionary" policy changes. Automatic stabilizers arise from spending programs and tax laws that adjust systematically with economic conditions. For example, economic downturns raise unemployment compensation and other spending programs. They also reduce tax revenues and, with a progressive tax code, tax rates. Discretionary policy changes require Congressional actions to create new spending initiatives or alter existing tax laws to counteract economic conditions. As Ando and Brown (1963), Stein (1996), Minarik (1991), and Taylor (2000) document, discretionary responses to cyclical variations occur in fits and starts.

For our present purposes, nothing rests on the precise mechanism that produces countercyclical policies. It is the expected response of future policies that matters. In terms of current fiscal policies, countercyclical policy corresponds to lower than normal output bringing forth a lower than normal tax rate and higher than normal government expenditure shares. Figure 1 depicts the policy variables; vertical lines mark NBER business cycle peaks and troughs.

Monetary policy responds over the cycle to two factors. First, to accommodate the decline in money demand associated with an economic contraction, the Federal Reserve reduces money growth. Second, to counteract the downturn, the Fed reduces the nominal interest rate by increasing the growth of high-powered money. The net effect is procyclical money growth, which appears in statistical characterizations of the data [Cooley and Hansen 1995]. This implies that seigniorage revenues tend to decline when output falls.

Table 1 reports the time series facts. ${ }^{7}$ Correlations among cyclical components of output and policy suggest very strong countercyclical behavior, as the last column indicates. Both components of government spending, consumption and transfer payments, rise when output falls below trend and both components of revenues, direct taxes and seigniorage, fall with output. The resulting budget deficit is financed by debt expansion, so the debt-output ratio rises during economic downturns.

Thorny issues arise in connecting the theory to quarterly U.S. data from 1954-2002. Because human capital investment is not separately recorded in national income accounts, it must be gleaned from existing data. One approach is to extract the human capital investment components of consumption, investment, and government consumption. Chari, Jones, and Manuelli (1995), for example, interpret human capital

\footnotetext{
${ }^{7} s^{g}$ and $s^{z}$ are ratios of total government consumption plus gross investment and transfer payments to output; $\tau$ is the average tax rate, computed as total government receipts divided by output; $\rho$ is the quarterly growth rate of the monetary base.
} 
investment as composed of health care plus education expenditures, which are components of personal consumption expenditures and government consumption.

Instead, we make the assumption that human capital investment consists largely of non-market activities not captured by national income accounts. The model implies that along a balanced growth path when $\delta_{k}=\delta_{h}, h_{t} / k_{t}=x_{h t} / x_{k t}=(1-\sigma) / \sigma$. We use this relationship to impute human capital investment, $x_{h t}$, from data on physical capital investment, $x_{k t}$. Our assumption also implies that measured GDP misses the contribution of human capital, so we construct GDP from (1) as $y_{t}=c_{t}+x_{k t}+x_{h t}+g_{t}$. We define $c$ as personal consumption expenditures on nondurables plus services, $x_{k}$ as gross private domestic investment plus durables consumption, and $g$ as federal plus state and local consumption plus gross investment. In all the results that follow $y$ denotes this constructed output notion. ${ }^{8}$

\section{Calibration}

The calibration is designed to match certain aspects of the long-run behavior of the U.S. economy. We interpret that long-run behavior as the stationary equilibrium that emerges from the model when policy variables are constant at $\left(\tau, s^{g}, s^{z}, \rho\right)$. Constant policy variables imply constant expectations functions, $(\mu, \eta)$.

We interpret a time period in the model to be a quarter, so we set $\beta=.9877$ (Cooley and Prescott 1995). Our method of introducing capital depreciation, shown in (2) and $(3)$, creates links between the capital share parameter, $\sigma$, and the depreciation rate, $\delta$, that implies that our capital share parameter should be scaled by $(1-\delta)$ to make it comparable to the share parameter in models where depreciation is proportional to the capital stock. ${ }^{9}$ With a standard capital share of .36 (Chari, Christiano, and Kehoe $1994)$, we set $\sigma=.36 /(1-\delta)$. We choose the model's two remaining free parameters, $\delta$ and the ratio $\gamma / \alpha$, to match time averages of actual U.S. data. We choose $\delta$ to equate the model's ratio $x_{k} /\left(c+x_{k}\right)$ to the investment-private expenditures ratio in U.S. data. This implies $\delta_{k}=\delta_{h}=.0312$. In the equilibrium $\gamma$ and $\alpha$ appear only as a ratio. We choose $\gamma / \alpha=.01134$ to match the mean of velocity, $\left(c+x_{k}\right) / M / P .{ }^{10}$ Table 2 summarizes the calibration.

The calibration implies a seigniorage-output ratio of .0024, consistent with U.S. data, and transactions services as a share of output of .015. Diaz-Gimenez, Prescott,

\footnotetext{
${ }^{8}$ Appendix B describes the data.

${ }^{9}$ Consider Chari, Jones, and Manuelli's (1995) specification: $f(k, h)=k^{\alpha} h^{1-\alpha}, k_{t}=x_{k t}+(1-$ d) $k_{t-1}, h_{t}=x_{h t}+(1-d) h_{t-1}$. The return on a unit of investment in $k$, excluding undepreciated capital, is $\alpha f / k$. The comparable return in our model is $\sigma(1-\delta) f / k$, so to make the two capital shares comparable, we set $\sigma=\alpha /(1-\delta)$, where $\delta$ is the depreciation rate in our model.

${ }^{10}$ From 1954-2002, in U.S. data, $x_{k} /\left(c+x_{k}\right)=.25$ and $\left(c+x_{k}\right) / M / P=3.03$.
} 
Fitzgerald, and Alvarez (1992) estimate the size of the U.S. financial intermediary sector at between 3 and 7 percent of GNP while Aiyagari, Braun, and Eckstein (1998) calculate the cost to commercial banks of providing demand deposits and credit cards to be between .5 and 1.1 percent of GNP. Our value of $P_{T} T / y$ seems reasonable.

We compute perfect foresight policy paths as a benchmark for specifying expectations. While this represents a limiting case in terms of how much information agents possess about policy realizations, it is agnostic about policy behavior by not assuming policy obeys time-invariant functions. ${ }^{11}$ Moreover, the $\left\{\mu_{t}, \eta_{t}\right\}$ sequences derived from realizations of U.S. policy variables reflect any dynamic interactions of the kind discussed in section 3.4 that are embedded in actual policy behavior. Perfect foresight provides a benchmark to be contrasted with econometric methods for estimating expectations. Applying perfect foresight to compute the functions $\left\{\mu_{t}, \eta_{t}\right\}$ over the sample $t=1,2, \ldots, T$ requires specifying expected values of policy variables beyond the sample. We assume policy realizations beyond the sample equal their means over the full sample. ${ }^{12}$ To avoid solving a system of non-linear equations at each date, we exploit recursive representations of $\left\{\mu_{t}, \eta_{t}\right\}$ recorded in Appendix A.

\section{Simulations}

In addition to expressions (18) and (21), we report simulated paths for two other variables that define investment and velocity more broadly. The additional variables are the investment-output ratio, where investment includes physical and human capital investment,

$$
\frac{x_{t}}{y_{t}}=\frac{\left[\delta_{\sigma}\left(1-s_{t}^{g}\right)-\frac{1}{\eta_{t}}\left(1-\delta_{\sigma} s_{t}^{g}\right)\right]}{\delta_{\sigma}},
$$

and the income velocity of money

$$
v_{y t} \equiv \frac{y_{t}}{M_{t} / P_{t}}=\frac{1}{\Delta_{t}\left(1-s_{t}^{g}\right)} .
$$

U.S. data on portfolio choices exhibits clear cyclical patterns. Figure 2 plots the cyclical components of two investment shares: $x_{k} /\left(c+x_{k}\right)$ and $x / y$. The latter share

\footnotetext{
${ }^{11}$ Perfect foresight is a limiting case of the idea that agents have good information about tax rates and government spending some quarters into the future. See Yang (2003) for a historical accounting of the degree of foresight about U.S. tax policy and Yang (2004) for an exploration of the impact of foresight on inferences about tax policy impacts.

${ }^{12}$ The handling of post-sample expectations has little effect on the cyclical properties of the ratios $x_{k} /\left(c+x_{k}\right)$ and $\left(c+x_{k}\right) / M / P$, though it does affects the levels. See Gordon and Leeper (2000) for sensitivity analysis in a closely related model.
} 
uses imputed data to compute both $x$ and $y$. Vertical lines mark NBER business

cycle dates. Investment tends to peak just before business cycle peaks, while its troughs coincide with business cycle troughs. Figure 3 records the cyclical parts of two measures of velocity: $\left(c+x_{k}\right) / M / P$ and $y / M / P$. Again, the latter measure uses imputed data to compute $y$. Velocity is also procyclical, though its peaks and troughs align less well with the business cycle.

Figure 4 shows the cyclical components of the model's investment shares. Both series exhibit cyclical behavior that coincides with the U.S. business cycle. Investment is strongly procyclical in the data and the model reproduces this cyclicality remarkably well. In many instances model investment reaches a cyclical peak or trough in precisely the same quarter that U.S. data does, though its volatility is less than in data. The model even produces investment booms that coincide with actual data (1965-1966, late 1972-early 1973, and 1984).

Figure 5 shows the cyclical parts of the model's velocity measures. Model velocity is weakly procyclical, falling in at least half the recessions. Rarely do its cyclical troughs coincide with those of U.S. velocity, although velocity's general cyclical pattern does mimic actual data, especially in the past 30 years.

Table 3 compares summary statistics for our two investment shares and velocity measures from U.S. data and the model. The model explains $24 \%$ to $38 \%$ of variation in the level of the investment shares, and $21 \%$ to $34 \%$ at cyclical frequencies. It also accounts for $29 \%$ to $33 \%$ of the standard deviation of the level of velocity, and $57 \%$ to $73 \%$ at cyclical frequencies. Simulated data is highly persistent and its cyclical components are even more persistent than U.S. data.

\section{Concluding Remarks}

These results are startling. All variation in the model stems from realizations of current and expected future macro policies. If policy variables were constant, simulated data would be constant. The cyclical pattern exhibited by simulated data arises from countercyclical policies. Evidently, those policies have counterproductive impacts. 


\section{Appendix A. Model Derivations}

A.1. First-Order Conditions. The first-order conditions for the two kinds of firms yield

$$
\begin{gathered}
r_{t}=f_{k}(t), \\
w_{t} n_{t}=f_{h}(t), \\
w_{t} h_{t-1}=f_{n}(t), \\
w_{T t}=P_{T t} T^{\prime}\left(l_{t}\right) .
\end{gathered}
$$

Let $\varphi$ be the lagrange multiplier on the household's budget constraint and $\lambda$ be the multiplier on the finance constraint. The household's first-order conditions are:

$$
\begin{aligned}
& c_{t}: \quad U_{c}(t)-\varphi_{t}-\lambda_{t}\left(1-T_{t}\right)=0 \\
& l_{t}: \quad U_{l}(t)+\varphi_{t} w_{T t}=0 \\
& n_{t}: \quad U_{n}(t)+\varphi_{t}\left[\left(1-\tau_{t}^{n}\right) w_{t} h_{t-1}+\tau_{t}^{k} d_{n}^{k}(t)+\tau_{t}^{n} d_{n}^{h}(t)\right] \\
& +\lambda_{t}\left(1-T_{t}\right)\left[d_{n}^{k}(t)+d_{n}^{h}(t)\right]=0 \\
& T_{t}: \quad-\varphi_{t} P_{T t}+\lambda_{t}\left(c_{t}+x_{t}\right)=0 \\
& M_{t}: \quad-\frac{\varphi_{t}}{P_{t}}+\beta E_{t}\left[\frac{\varphi_{t+1}+\lambda_{t+1}}{P_{t+1}}\right]=0 \\
& B_{t}: \quad-\frac{\varphi_{t}}{P_{t}}+\beta\left(1+i_{t}\right) E_{t} \frac{\varphi_{t+1}}{P_{t+1}}=0 \\
& k_{t}: \quad-\varphi_{t}-\lambda_{t}\left(1-T_{t}\right) \\
& +\beta E_{t}\left\{\varphi_{t+1}\left[\left(1-\tau_{t+1}^{k}\right) r_{t+1}+\tau_{t+1}^{k} d_{k}^{k}(t+1)+\tau_{t+1}^{n} d_{k}^{h}(t+1)\right]\right. \\
& \left.+\lambda_{t+1}\left(1-T_{t+1}\right)\left[d_{k}^{k}(t+1)+d_{k}^{h}(t+1)\right]\right\}=0 \\
& h_{t}: \quad-\varphi_{t}-\lambda_{t}\left(1-T_{t}\right) \\
& +\beta E_{t}\left\{\varphi_{t+1}\left[\left(1-\tau_{t+1}^{n}\right) w_{t+1} n_{t+1}+\tau_{t+1}^{k} d_{h}^{k}(t+1)+\tau_{t+1}^{n} d_{h}^{h}(t+1)\right]\right. \\
& \left.+\lambda_{t+1}\left(1-T_{t+1}\right)\left[d_{h}^{k}(t+1)+d_{h}^{h}(t+1)\right]\right\}
\end{aligned}
$$


A.2. Some Accounting. The following accounting identities are useful in solving the model. Total goods must equal gross assets:

$$
\begin{gathered}
c_{t}+k_{t}+h_{t}+g_{t}=f\left(k_{t-1}, h_{t-1} n_{t}\right), \\
y_{t}=f\left(k_{t-1}, h_{t-1} n_{t}\right)-d^{k}\left(k_{t-1}, h_{t-1} n_{t}\right)-d^{h}\left(k_{t-1}, h_{t-1} n_{t}\right), \\
c_{t}+k_{t}+h_{t}=\left(1-\delta_{\sigma} s_{t}^{g}\right) f(t),
\end{gathered}
$$

and define the share-weighted average depreciation rate as

$$
\delta_{\sigma}=1-\sigma\left(1-\delta_{k}\right)-(1-\sigma)\left(1-\delta_{h}\right) .
$$

From (42) and (60),

$$
\begin{gathered}
y_{t}=\delta_{\sigma} f(t), \\
c_{t}+x_{t}=\left(1-s_{t}^{g}\right) y_{t}=\delta_{\sigma}\left(1-s_{t}^{g}\right) f(t) .
\end{gathered}
$$

Define

$$
s_{t}=\frac{x_{t}}{c_{t}+x_{t}},
$$

and

$$
\widetilde{s_{t}}=\frac{k_{t}+h_{t}}{c_{t}+k_{t}+h_{t}}=\frac{k_{t}+h_{t}}{\left(1-\delta_{\sigma} s_{t}^{g}\right) f(t)},
$$

so the relationship between $s_{t}$ and $\widetilde{s_{t}}$ is

$$
\begin{gathered}
\frac{1}{1-s_{t}}=\frac{\delta_{\sigma}\left(1-s_{t}^{g}\right)}{1-\delta_{\sigma} s_{t}^{g}} \cdot \frac{1}{1-\widetilde{s_{t}}} . \\
\frac{f(t)}{c_{t}}=\frac{1}{1-\delta_{\sigma} s_{t}^{g}} \cdot \frac{1}{1-\widetilde{s_{t}}}=\frac{1}{\delta_{\sigma}\left(1-s_{t}^{g}\right)} \cdot \frac{1}{1-s_{t}}, \\
\frac{f(t)}{c_{t}+x_{t}}=\frac{1}{\delta_{\sigma}\left(1-s_{t}^{g}\right)} .
\end{gathered}
$$


A.3. Solving the Model. The lagrange multipliers are

$$
\begin{gathered}
\varphi_{t}=\frac{1}{c_{t}}-\frac{\gamma / \alpha}{c_{t}+x_{t}}, \\
\lambda_{t}=\frac{\gamma / \alpha}{\left(1-T_{t}\right)\left(c_{t}+x_{t}\right)} .
\end{gathered}
$$

The Euler equation for physical capital, (39) can be reduced to

$$
\begin{aligned}
\frac{k_{t}}{c_{t}}= & \sigma \beta E_{t}\left\{\left[\frac{\left(1-\tau_{t+1}^{k}\right)+\tau_{t+1}^{k} \sigma\left(1-\delta_{k}\right)+\tau_{t+1}^{n}(1-\sigma)\left(1-\delta_{h}\right)}{1-\delta_{\sigma} s_{t+1}^{g}}\right] \frac{1}{1-\tilde{s}_{t+1}}\right. \\
& \left.-\frac{\gamma}{\alpha}\left[\frac{\left(1-\tau_{t+1}^{k}\right)-\left(1-\tau_{t+1}^{k}\right) \sigma\left(1-\delta_{k}\right)-\left(1-\tau_{t+1}^{n}\right)(1-\sigma)\left(1-\delta_{h}\right)}{\delta_{\sigma}\left(1-s_{t+1}^{g}\right)}\right]\right\}
\end{aligned}
$$

and

$$
\begin{aligned}
\frac{h_{t}}{c_{t}}= & \sigma \beta E_{t}\left\{\left[\frac{\left(1-\tau_{t+1}^{n}\right)+\tau_{t+1}^{k} \sigma\left(1-\delta_{k}\right)+\tau_{t+1}^{n}(1-\sigma)\left(1-\delta_{h}\right)}{1-\delta_{\sigma} s_{t+1}^{g}}\right] \frac{1}{1-\tilde{s}_{t+1}}\right. \\
& \left.-\frac{\gamma}{\alpha}\left[\frac{\left(1-\tau_{t+1}^{n}\right)-\left(1-\tau_{t+1}^{k}\right) \sigma\left(1-\delta_{k}\right)-\left(1-\tau_{t+1}^{n}\right)(1-\sigma)\left(1-\delta_{h}\right)}{\delta_{\sigma}\left(1-s_{t+1}^{g}\right)}\right]\right\}
\end{aligned}
$$

In the special case on which we focus, where $\tau^{k}=\tau^{n}=\tau,(54)$ and (55) further simplify to

$$
\frac{k_{t}}{c_{t}}=\sigma \beta E_{t}\left\{\left[\frac{1-\delta_{\sigma} \tau_{t+1}}{1-\delta_{\sigma} s_{t+1}^{g}}\right] \frac{1}{1-\tilde{s}_{t+1}}-\frac{\gamma}{\alpha}\left(\frac{1-\tau_{t+1}}{1-s_{t+1}^{g}}\right)\right\}
$$

and

$$
\frac{h_{t}}{c_{t}}=(1-\sigma) \beta E_{t}\left\{\left[\frac{1-\delta_{\sigma} \tau_{t+1}}{1-\delta_{\sigma} s_{t+1}^{g}}\right] \frac{1}{1-\tilde{s}_{t+1}}-\frac{\gamma}{\alpha}\left(\frac{1-\tau_{t+1}}{1-s_{t+1}^{g}}\right)\right\} .
$$

Note that along an equilibrium growth path, (56) and (57) imply

$$
\frac{k_{t}}{h_{t}}=\frac{\sigma}{1-\sigma} .
$$

Adding (56) and (57) yields a difference equation in $\tilde{s}$ :

$$
\frac{1}{1-\tilde{s}_{t}}=\beta E_{t}\left[\frac{1-\delta_{\sigma} \tau_{t+1}}{1-\delta_{\sigma} s_{t+1}^{g}}\right] \frac{1}{1-\tilde{s}_{t+1}}+E_{t}\left[1-\beta \frac{\gamma}{\alpha}\left(\frac{1-\tau_{t+1}}{1-s_{t+1}^{g}}\right)\right],
$$

where

$$
\delta_{\sigma}=1-\sigma\left(1-\delta_{k}\right)-(1-\sigma)\left(1-\delta_{h}\right) .
$$

The solution to this difference equation is

$$
\frac{1}{1-\tilde{s}_{t}}=\eta_{t},
$$


where

$$
\eta_{t}=E_{t} \sum_{i=0}^{\infty} \beta^{i} d_{i}^{\eta}\left[1-\beta \frac{\gamma}{\alpha}\left(\frac{1-\tau_{t+i+1}}{1-s_{t+i+1}^{g}}\right)\right], \quad d_{i}^{\eta}=\prod_{j=0}^{i-1} \frac{1-\delta_{\sigma} \tau_{t+j+1}}{1-\delta_{\sigma} s_{t+j+1}^{g}}, \quad d_{0}^{\eta}=1
$$

Convergence of (59) imposes restrictions on the policy processes, $\left\{\tau_{t}, s_{t}^{g}\right\}$, such that

$$
\lim _{k \rightarrow \infty} \beta^{k} E_{t} \prod_{j=1}^{k}\left[\frac{1-\delta_{\sigma} \tau_{t+j}}{1-\delta_{\sigma} s_{t+j}^{g}}\right] \frac{1}{1-\tilde{s}_{t+k}}=0
$$

The Euler equation for money yields the difference equation

$$
\left(1-T_{t}\right)\left[\frac{1}{1-s_{t}}-\frac{\gamma}{\alpha}\right]=\beta \frac{1}{\rho_{t}} E_{t}\left\{\left(1-T_{t+1}\right)\left[\frac{1}{1-s_{t+1}}-\frac{\gamma}{\alpha}\right]+\frac{\gamma}{\alpha}\right\},
$$

whose solution is

$$
\left(1-T_{t}\right)\left[\frac{1}{1-s_{t}}-\frac{\gamma}{\alpha}\right]=\frac{\mu_{t}}{\rho_{t}}
$$

where $\rho_{t} \equiv M_{t} / M_{t-1}$ and

$$
\mu_{t} \equiv \beta \frac{\gamma}{\alpha} E_{t} \sum_{i=0}^{\infty} \beta^{i} d_{i}^{\mu}, \quad d_{i}^{\mu} \equiv \prod_{j=0}^{i-1} \frac{1}{\rho_{t+j+1}}, \quad d_{0}^{\mu} \equiv 1
$$

Convergence of (64) imposes restrictions on the policy process $\left\{\rho_{t}\right\}$ such that

$$
\lim _{k \rightarrow \infty} \beta^{k} E_{t} \prod_{j=1}^{k} \frac{1}{\rho_{t+j-1}}\left(1-T_{t+k}\right)\left[\frac{1}{1-s_{t+k}}-\frac{\gamma}{\alpha}\right]=0
$$

A.4. Recursive Representations. Note that $\mu_{t}$ and $\eta_{t}$ have the following recursive representations:

$$
\begin{gathered}
\mu_{t}=\beta\left(\frac{\gamma}{\alpha}+E_{t} \frac{\mu_{t+1}}{\rho_{t+1}}\right), \\
\eta_{t}=1-\beta \frac{\gamma}{\alpha} E_{t}\left(\frac{1-\tau_{t+1}}{1-s_{t+1}^{g}}\right)+\beta E_{t}\left(\frac{1-\delta_{\sigma} \tau_{t+1}}{1-\delta_{\sigma} s_{t+1}^{g}}\right) \eta_{t+1} .
\end{gathered}
$$


Appendix B. Data

Unless otherwise indicated, all data are from the Bureau of Economic Analysis.

$c$ : Personal consumption expenditures on nondurables plus services, chained 1996 dollars.

$x_{k}$ : Personal consumption expenditures on durables plus gross private domestic investment, chained 1996 dollars.

$G_{F}$ : Federal government consumption expenditures and gross investment, current dollars.

$G$ : Federal plus state and local government consumption expenditures and gross investment, current dollars.

$P$ : Implicit GDP deflator, chained.

$g_{F}$ :Real federal government consumption expenditures and gross investment $=$ $G_{F} / P$.

$g$ : Real state and local government consumption expenditures and gross investment $=G / P$.

$T_{F}$ : Total federal government tax receipts, current dollars.

$T$ : Total federal plus state and local government tax receipts, current dollars.

$Z_{F}$ : Total federal government transfers $=$ transfers to persons + grants-in-aid to state and local governments + net interest + subsidies less current surplus of government enterprises.

$Z_{S L}$ : Total state and local government transfers $=$ transfers to persons + net interest + subsidies less current surplus of government enterprises.

$Z$ : Total federal plus state and local government transfers $=Z_{F}+Z_{S L}$.

$z:$ Real total federal plus state and local government transfers $=Z / P$.

$z_{F}$ : Real total federal government transfers $=Z_{F} / P$.

$y_{F}$ : Output (federal government only) $=c+x_{k}+g_{F}$.

$y$ : Output (federal plus state and local government) $=c+x_{k}+g$.

$\tau_{F}$ : Average tax rate (federal government only) $=T_{F} /\left(P y_{F}\right)$.

$\tau$ : Average tax rate (federal plus state and local government) $=T /(P y)$.

$s_{F}^{g}$ : Federal government consumption and gross investment as share of output $=g_{F} / y_{F}$.

$s^{g}$ : Federal plus state and local government consumption and gross investment as share of output $=g / y$.

$s_{F}^{z}$ : Federal government transfers as share of output $=z_{F} / y_{F}$.

$s^{z}$ : Federal plus state and local government transfers as share of output $=z / y$.

$k$ : Real capital stock $=$ fixed assets (under produced assets, NIPA Table 5.16, line 45) + nonfarm business inventories. 
$M$ : Source base, current dollars, Federal Reserve Bank of St. Louis, NSA, seasonally adjusted using Census Bureau's x12xp program.

$\rho_{t}$ : Money growth rate $=M_{t} / M_{t-1}$.

$B$ : Market value of privately held gross federal government debt, current dollars, Federal Reserve Bank of Dallas.

$$
\begin{aligned}
& V_{c x_{k}}=\left(c+x_{k}\right) / M / P . \\
& V_{y_{F}}=y_{F} / M / P . \\
& V_{y}=y / M / P . \\
& c y_{F}=c / y_{F} . \\
& c y=c / y . \\
& x_{k} y_{F}=x_{k} / y_{F} . \\
& x_{k} y=x_{k} / y .
\end{aligned}
$$




\section{REFERENCES}

Aiyagari, S. R., R. A. Braun, and Z. Eckstein (1998): "Transaction Services, Inflation, and Welfare," Journal of Political Economy, 106(December), 1274-1301. Ando, A., And E. C. Brown (1963): "Lags in Fiscal Policy," in Stabilization Policies, Commission on Money and Credit, pp. 97-163. Prentice-Hall, Inc., Englewood Cliffs, NJ.

Auerbach, A. J. (2003): "Fiscal Policy, Past and Present," Brookings Papers on Economic Activity, (1), 75-122.

Auerbach, A. J., And D. Feenberg (2000): "The Significance of Federal Taxes as Automatic Stabilizers," Journal of Economic Perspectives, 14(Summer), 37-56.

Baily, M. N. (1978): "Stabilization Policy and Private Economic Behavior," Brookings Papers on Economic Activity, 1, 11-50.

Baxter, M., And R. G. King (1993): "Fiscal Policy in General Equilibrium," American Economic Review, 86, 1154-1174.

(1999): "Measuring Business Cycles: Approximate Band-Pass Filters for Economic Time Series," Review of Economics and Statistics, 81(November), 575593.

Blinder, A. S., And R. M. Solow (1973): "Does Fiscal Policy Matter?," Journal of Public Economics, 2(November), 319-337.

Bohn, H. (1991): "Budget Balance through Revenue or Spending Adjustments? Some historical Evidence for the United States," Journal of Monetary Economics, 27 (June), 333-359.

Chari, V. V., L. J. Christiano, and P. J. Kehoe (1994): "Optimal Fiscal Policy in a Business Cycle Model," Journal of Political Economy, 102(August), 617-652.

Chari, V. V., L. E. Jones, and R. E. Manuelli (1995): "The Growth Effects of Monetary Policy," Federal Reserve Bank of Minneapolis Quarterly Review, 19, $18-32$.

Chatterjee, S. (1999): "Real Business Cycles: A Legacy of Countercyclical Policies?," Federal Reserve Bank of Philadelphia Business Review, (January/February), $17-27$.

Christiano, L. J. (1984): "A Reexamination of the Theory of Automatic Stabilizers," vol. North-Holland of Carnegie-Rochester Conference Series on Public Policy, pp. 147-206. Amsterdam.

Cohen, D., and G. Follette (2000): "The Automatic Fiscal Stabilizers: Quietly Doing Their Thing," Federal Reserve Bank of New York Policy Review, 6, 35-68. Cooley, T. F., and G. D. Hansen (1995): "Money and the Business Cycle," in Frontiers of Business Cycle Research, ed. by T. F. Cooley, pp. 175-216. Princeton 
University Press, Princeton, NJ.

Cooley, T. F., and E. C. Prescott (1995): "Economic Growth and Business Cycles," in Frontiers of Business Cycle Research, ed. by T. F. Cooley, pp. 1-38. Princeton University Press, Princeton, NJ.

Diaz-Gimenez, J., E. C. Prescott, T. J. Fitzgerald, and F. Alvarez (1992): "Banking in Computable General Equilibrium Economies," Journal of Economic Dynamics and Control, 16(July/October), 533-559.

Duesenberry, J. S., O. Eckstein, and G. Fromm (1960): "A Simulation of the United States in Recession," Econometrica, 28(October), 749-809.

Gordon, D. B., And E. M. Leeper (2000): "Can Countercyclical Policies Be Counterproductive?," Manuscript, Indiana University.

Hansen, B. (1969): Fiscal Policy in Seven Countries, 1955-1965. OECD, Paris.

Heckman, J. J. (1976): "A Life-Cycle Model of Earnings, Leanring, and Consumption," Journal of Political Economy, 84(No. 2, Pt. 2), S11-S44.

Jones, J. B. (2002): "Has Fiscal Policy Helped Stabilize the Postwar U.S. Economy?," Journal of Monetary Economics, 49(May), 709-746.

Jones, L. E., R. E. Manuelli, and P. E. Rossi (1993): "Optimal Taxation in Models of Endogenous Growth," Journal of Political Economy, 101(3), 485-517.

LucAs, JR., R. E. (1988): "On the Mechanics of Economic Development," Journal of Monetary Economics, 22(July), 3-42.

Minarik, J. J. (1991): "Countercyclical Fiscal Policy: In Theory, and in Congress," National Tax Journal, 44(September), 251-256.

Romer, C. D. (1999): "Changes in Business Cycles: Evidence and Explanations," Journal of Economic Perspectives, 13(Spring), 23-44.

Romer, C. D., and D. Romer (1994): "What Ends Recessions?," in NBER Macroeconomics Annual 1994, ed. by S. Fischer, and J. J. Rotemberg, pp. 13-57. MIT Press, Cambridge, MA.

Romer, C. D., And D. H. Romer (2002): "The Evolution of Economic Understanding and Postwar Stabilization Policy," in Rethinking Stabilization Policy, pp. 11-78. Federal Reserve Bank of Kansas City, Kansas City.

Sargent, T. J. (2002): "Commentary: The Evolution of Economic Understanding and Postwar Stabilization Policy," in Rethinking Stabilization Policy: Proceedings of a Symposium Sponsored by the Federal Reserve Bank of Kansas City, pp. 79-94.

Sargent, T. J., And N. Wallace (1981): "Some Unpleasant Monetarist Arithmetic," Federal Reserve Bank of Minneapolis Quarterly Review, 5(Fall), 1-17.

Stein, H. (1996): The Fiscal Revolution in America. AEI Press, Washington, D.C., second revised edn. 
TAYlor, J. B. (2000): "Reassessing Discretionary Fiscal Policy," Journal of Economic Perspectives, 14(3), 21-36.

Tobin, J. (1980): Asset Accumulation and Economic Activity. University of Chicago Press, Chicago.

YANG, S.-C. S. (2003): "The Chronology of Major Tax Events from 1947 to 2001 in the U.S.," mimeo, Indiana University.

(2004): "Quantifying Tax Effects Under Policy Foresight," Journal of Monetary Economics, forthcoming. 
TABle 1. Correlations of Policy Variables with Output

\begin{tabular}{|l|c|c|}
\hline \multicolumn{2}{|c|}{ Federal Plus State and Local Government } \\
\hline & \multicolumn{2}{c|}{ Correlation with Output } \\
\hline $\begin{array}{l}\text { Policy } \\
\text { Variable }\end{array}$ & Level & Cyclical Component \\
$1954: 1-2002: 4$ & $1957: 1-1999: 4$ \\
\hline \hline$s^{g}$ & -.94 & -.86 \\
\hline$s^{z}$ & .78 & -.85 \\
\hline Revenues & .99 & .73 \\
\hline$\rho$ & .42 & .28 \\
\hline seigniorage $/ y$ & .23 & n.a. \\
\hline B/Py & -.06 & -.40 \\
\hline \hline$s^{g}=g / y, s^{z}=z / y, \rho_{t}=M_{t} / M_{t-1}$. Cyclical components \\
derived from band-pass filtered data using Baxter and \\
Kings's $(1999)$ algorithm to extract frequencies between \\
2 and 32 quarters with 3 years of padding. \\
\hline
\end{tabular}


TABle 2. Model Parameters and Stationary Equilibrium versus U.S. Data

\begin{tabular}{|l||l|l|l|}
\hline \multicolumn{2}{|c|}{ Federal Plus State and Local Government } \\
\hline $\begin{array}{l}\text { Parameter } \\
\text { Values }\end{array}$ & Variable & $\begin{array}{l}\text { Stationary } \\
\text { State }\end{array}$ & $\begin{array}{l}\text { U.S. } \\
\text { Data }\end{array}$ \\
\hline$\beta=.9877$ & $x_{k} /\left(c+x_{k}\right)$ & .25 & .25 \\
$\sigma=.3716$ & $x / y$ & .40 & .40 \\
$\delta_{k}=.0312$ & $\left(c+x_{k}\right) / M / P$ & 3.03 & 3.03 \\
$\delta_{h}=.0312$ & $y / M / P$ & 5.13 & 5.14 \\
$\gamma / \alpha=.01134$ & $s^{g}$ & .156 & .156 \\
& $s^{z}$ & .093 & .093 \\
& $\tau$ & .201 & .201 \\
& $\rho$ & 1.0135 & 1.0135 \\
\hline Addendum & \multicolumn{3}{|c|}{. .0149. } \\
& $P_{T} T / y$ & .0026 \\
\hline \multicolumn{4}{|l}{ seigniorage/y } \\
Besults for federal plus state and local government.
\end{tabular}


Table 3. Portfolio Choice Statistics

\begin{tabular}{|c|c|c|c|c|}
\hline \multicolumn{5}{|c|}{ Results for Federal Plus State and Local Government } \\
\hline & $\begin{array}{l}\text { Level } \\
(\log )\end{array}$ & & $\begin{array}{c}\text { Cyclical } \\
\text { Component }\end{array}$ & \\
\hline Variable & $\begin{array}{l}\text { Std. Dev. } \\
(\%)\end{array}$ & $\begin{array}{c}\text { Serial } \\
\text { Correlation }\end{array}$ & $\begin{array}{l}\text { Std. Dev. } \\
(\%)\end{array}$ & $\begin{array}{c}\text { Serial } \\
\text { Correlation }\end{array}$ \\
\hline$x_{k} /\left(c+x_{k}\right)($ Data $)$ & 12.54 & .976 & 4.12 & .777 \\
\hline$x_{k} /\left(c+x_{k}\right)($ Model $)$ & 2.99 & .983 & .88 & .821 \\
\hline$x / y$ (Data) & 11.00 & .978 & 3.44 & .783 \\
\hline$x / y$ (Model) & 4.14 & .984 & 1.18 & .823 \\
\hline$v_{k}$ (Data) & 29.36 & .999 & 1.77 & .816 \\
\hline$v_{k}($ Model $)$ & 9.61 & .996 & 1.29 & .880 \\
\hline$v_{y}$ (Data) & 30.28 & .998 & 2.27 & .789 \\
\hline$v_{y}$ (Model) & 8.71 & .996 & 1.29 & .884 \\
\hline \multicolumn{5}{|c|}{$\begin{array}{l}\text { U.S. data from 1954:1-2002:4; filtered data from 1957:1-1999:4. } \\
y \text { denotes total output and is defined as } y=c+x+g \text {, where } x=x_{k}+x_{h} \text {. } \\
\text { For the production function } f(k, h)=k^{\sigma} h^{1-\sigma}, x_{h}=((1-\sigma) / \sigma) x_{k}, \\
\text { so for U.S. data, } x_{h} \text { is imputed from data on } x_{k} \text { using this factor. } \\
\text { Velocity measures are } v_{k}=\left(c+x_{k}\right) / M / P \text { and } v_{y}=y / M / P \text {. }\end{array}$} \\
\hline
\end{tabular}


Figure 1. U.S. Policy Variables

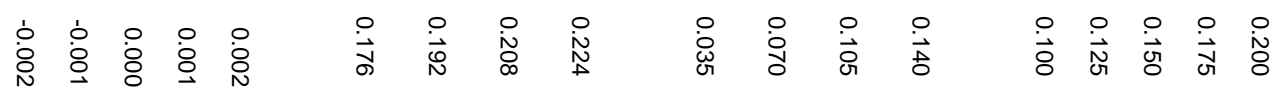
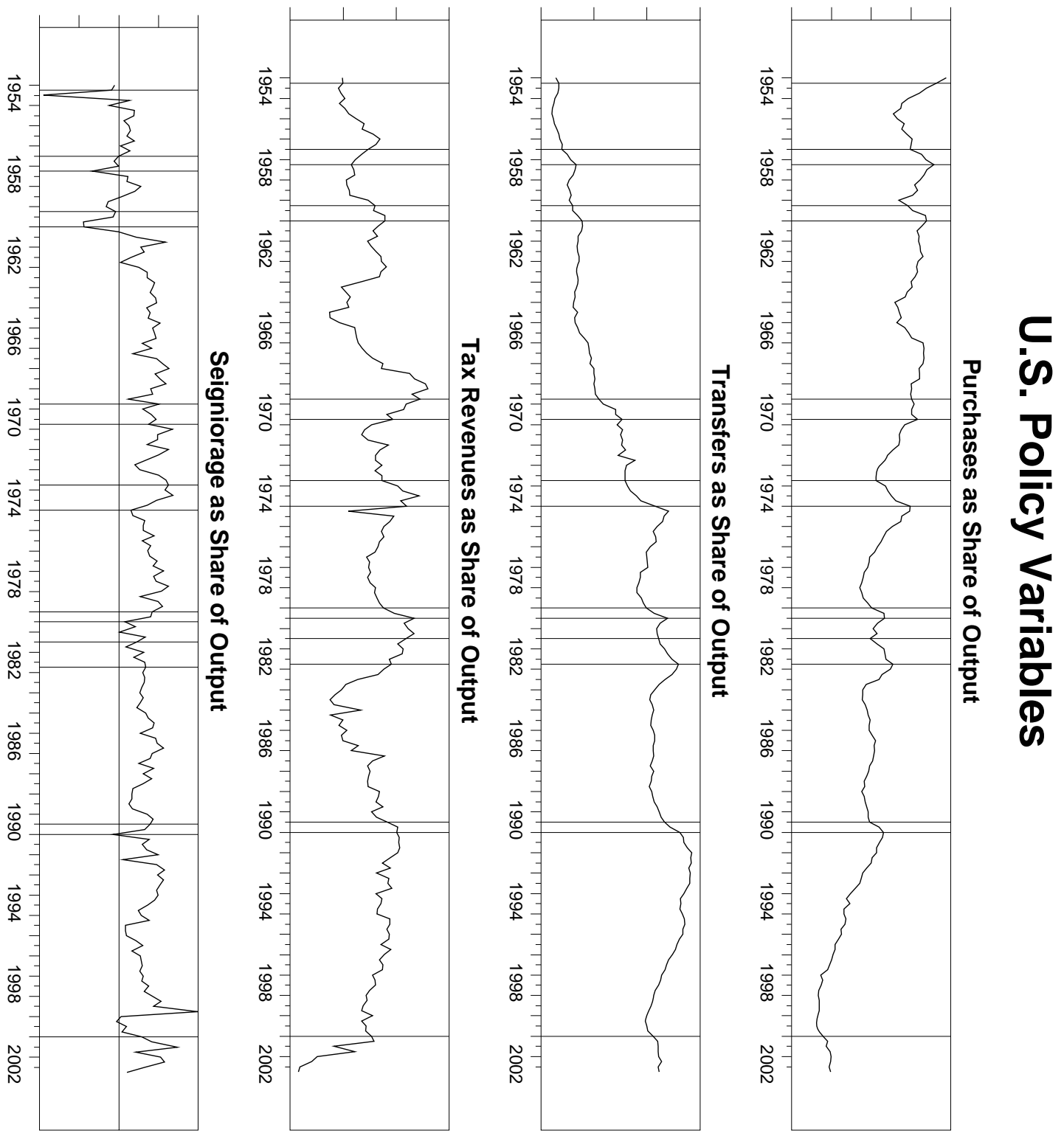
Figure 2. U.S. Data: Investment Shares

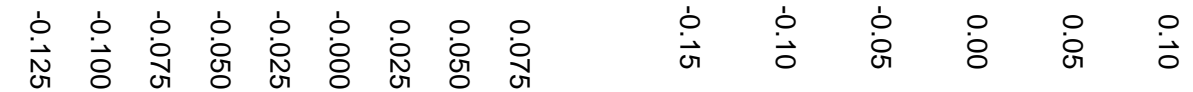
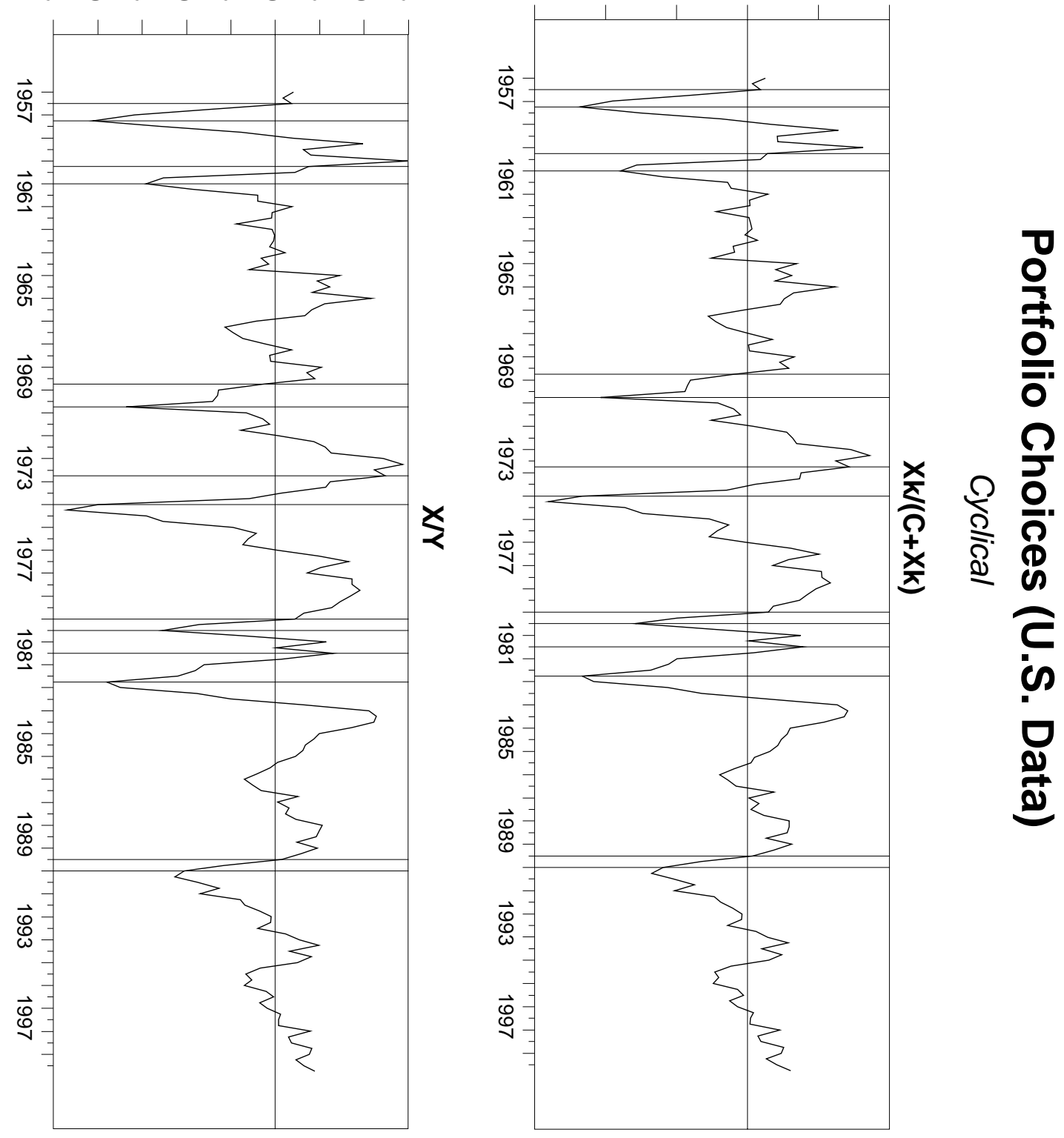
Figure 3. U.S. Data: Velocity

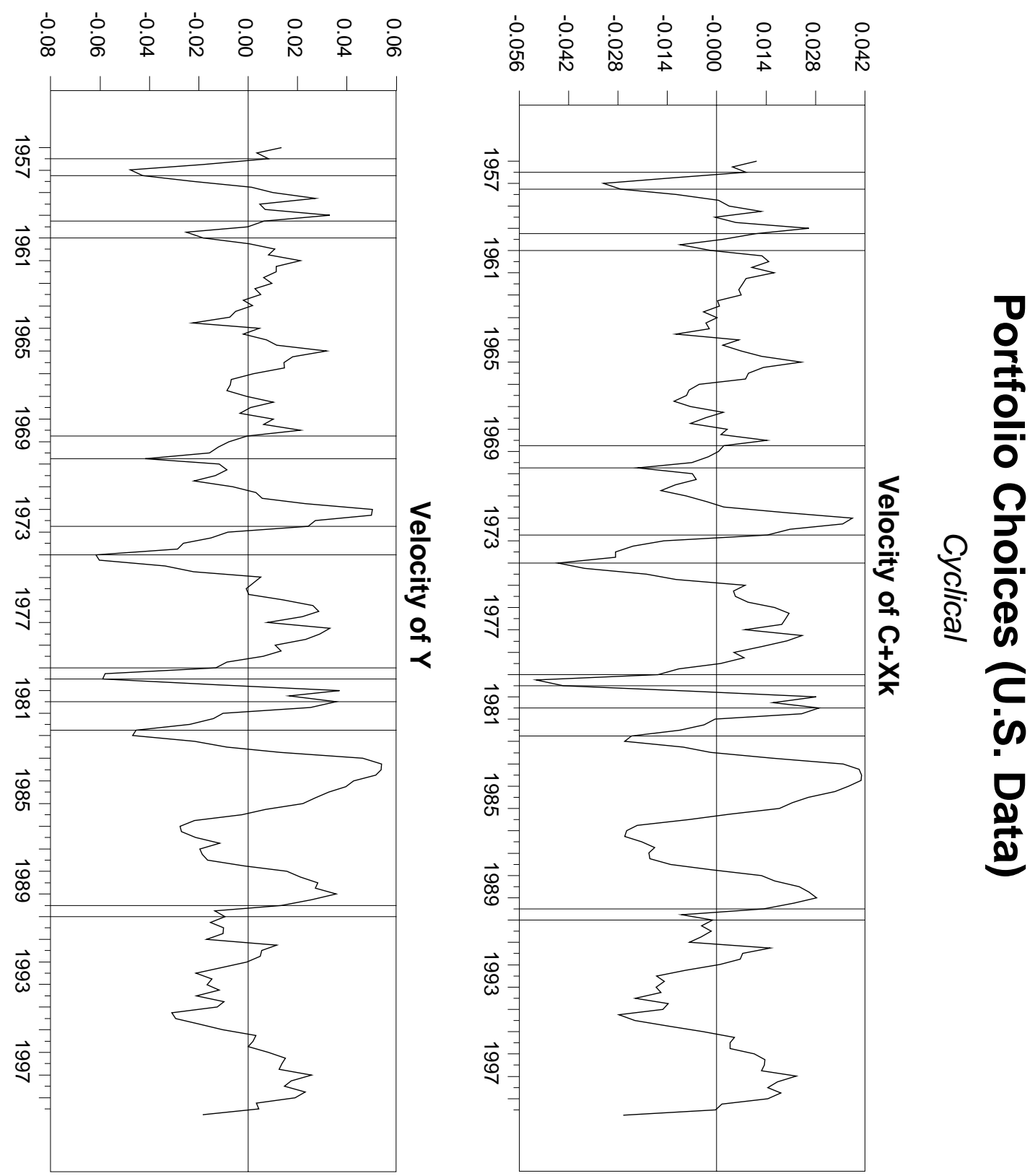


Figure 4. Perfect Foresight Model: Investment Shares
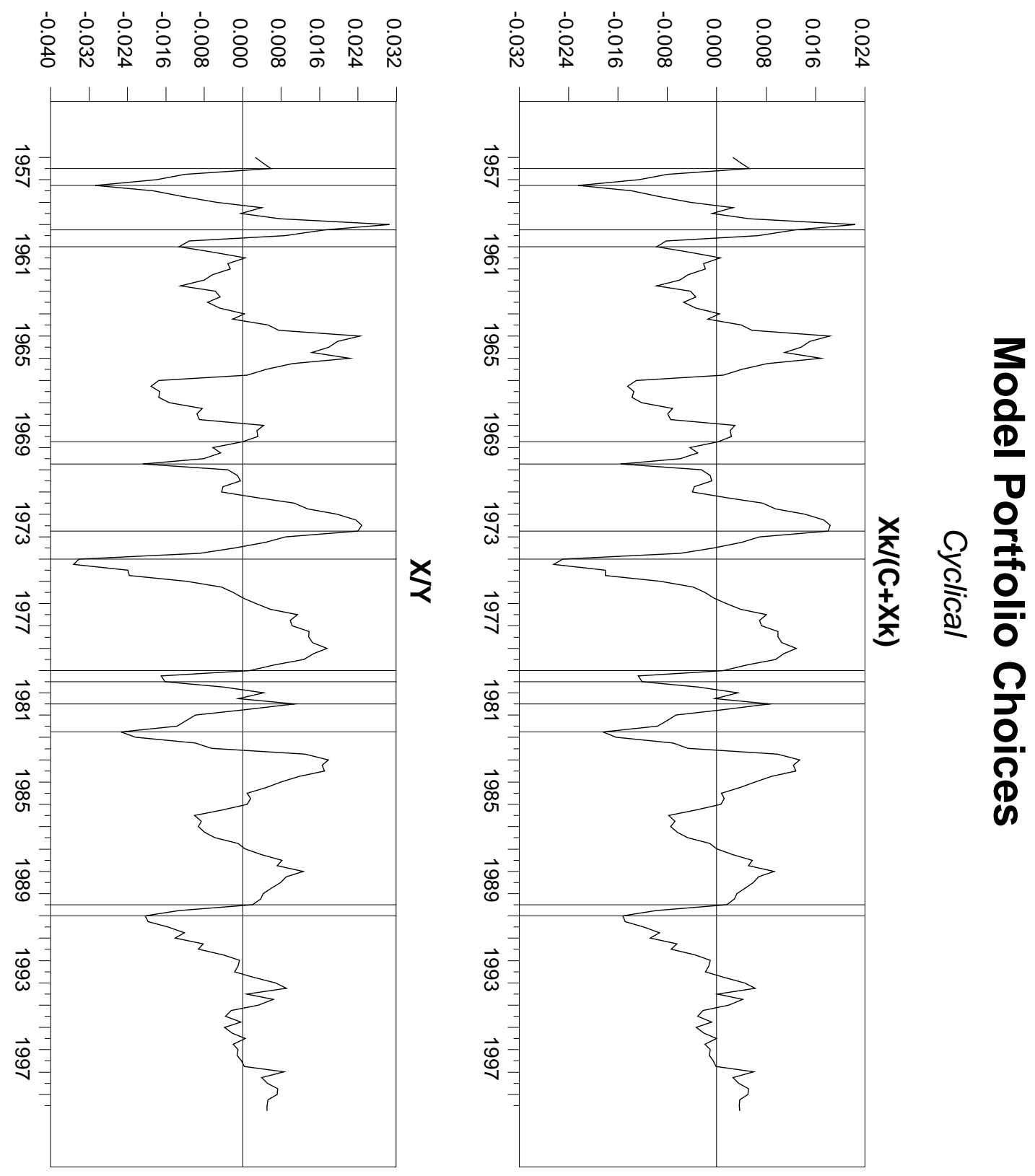
Figure 5. Perfect Foresight Model: Velocity

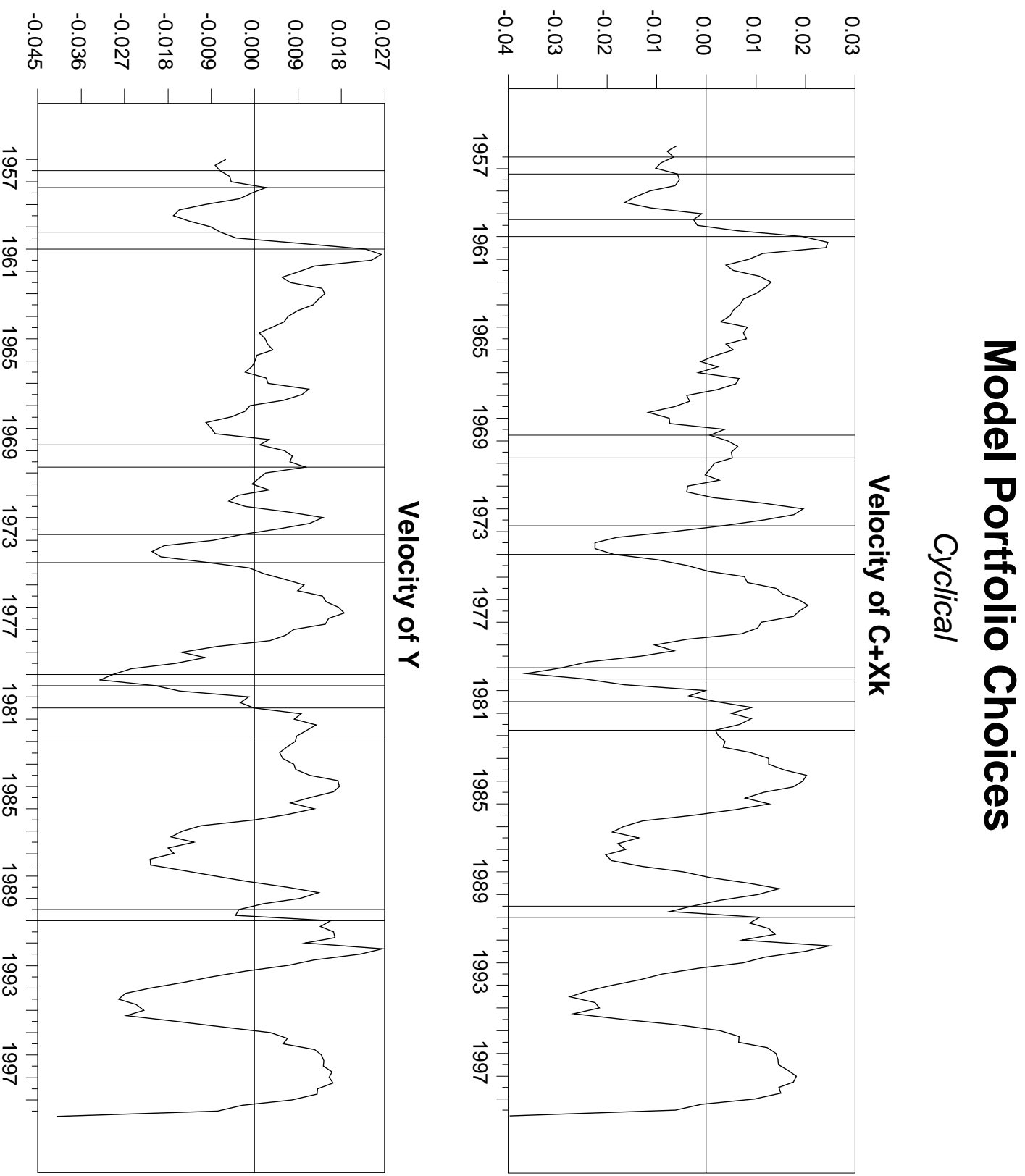

